
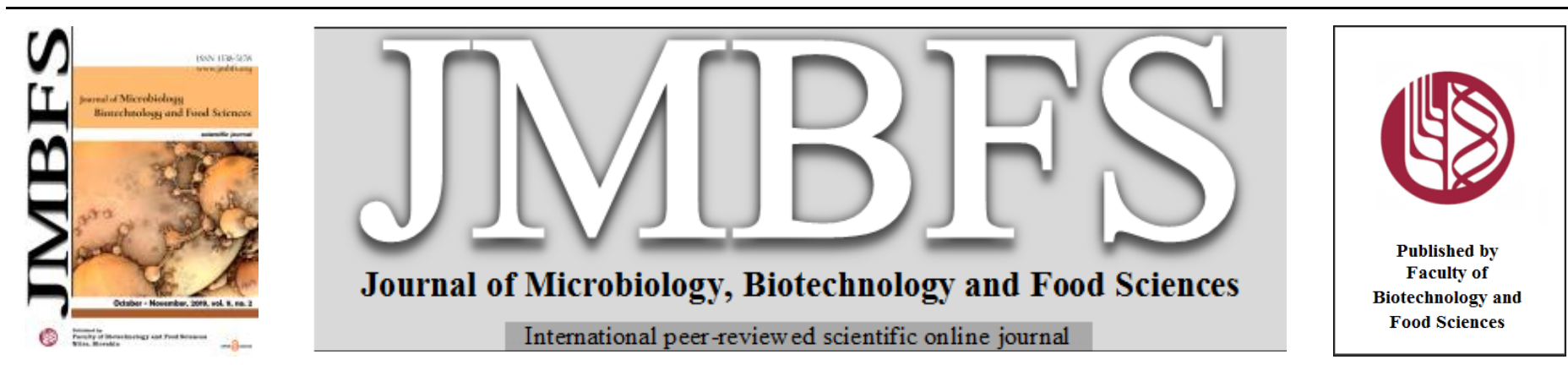

\title{
JUMBO SQUID (Dosidicus gigas) SKIN PIGMENTS: CHEMICAL ANALYSIS AND EVALUATION OF ANTIMICROBIAL AND ANTIMUTAGENIC POTENTIAL
}

\section{Jesús Enrique Chan-Higuera ${ }^{1,2}$, Angel Antonio Carbonell-Barrachina ${ }^{2}$, José Luis Cárdenas-López ${ }^{1}$, Miroslava Kačániová ${ }^{3,4}$, Armando Burgos-Hernández ${ }^{1}$, Josafat Marina Ezquerra-Brauer*I}

\author{
Address(es): Dr. Josafat Marina Ezquerra Brauer, \\ ${ }^{1}$ University of Sonora, Departamento de Investigación y Posgrado en Alimentos, Blvd. Luis Encinas y Rosales s/n, 83000 Hermosillo, Sonora, Mexico. \\ ${ }^{2}$ University Miguel Hernández de Elche (UMH), Departamento Tecnología Agroalimentaria, Ctra. De Beniel, Km 3.2, 03312 Orihuela, Alicante, Spain \\ ${ }^{3}$ Slovak University of Agriculture, Department of Microbiology, Faculty of Biotechnology and Food Science, Trieda Andreja Hlinku 609/2, 949 76 Nitra-Chrenová, \\ Eslovaquia.
}

${ }^{4}$ Rzeszow University, Faculty of Biology and Agriculture, Food Analysis, Al. Rejtana 16c35-959 Rzeszów, Poland.

*Corresponding author: josafat.ezquerra@unison.mx

doi: 10.15414/jmbfs.2019.9.2.349-353

\section{ARTICLE INFO}

Received 6. 6. 2019

Revised 10. 7. 2019

Accepted 2. 9. 2019

Published 1. 10. 2019

Regular article

open $\bigodot_{\text {ACCESS }}$

\begin{abstract}
There is a great potential to use seafood by-products to create new beneficial products for customers. In a continued exploration of new chemical compounds from seafood by-products, jumbo squid (Dosidicus gigas) skin pigmented methanolic extracts (JSSE) were evaluated for their antimicrobial and antimutagenic activities. Pigments of JSSE were extracted with a yield of $635 \mathrm{mg} / \mathrm{g}$ and oxygen radical absorbance capacity-fluorescein (ORAC) with $178 \mu \mathrm{mol}$ TE/g JSSE using optimal conditions: $25^{\circ} \mathrm{C}$ and 5 min of sonication, established by factorial analysis. The antimicrobial activity of JSSE was evaluated using the agar diffusion method. The JSSE showed more than 50\% inhibition against Haemophilys influenza, Listeria monocytogenes, Staphylococcus aureus, and Candida albicans. The high antimicrobial activity of JSSE ( $<90 \%)$ was detected in Salmonella enterica. The JSSE also inhibited mutation induced by aflatoxin $\mathrm{B}_{1}$ in the Salmonella tryphimurium strain TA98 ( $\left.>50 \%\right)$, but not in the TA100 strain $(<20 \%)$. Data on the solubility behaviour, the maximum absorbance $(440 \mathrm{~nm})$, protons observed in the ${ }^{1} \mathrm{H}$ NMR spectra, and the FT-IR spectra peak at $1742 \mathrm{~cm}^{-1}$ of JSSE, suggest that the compound responsible for its antimicrobial and antimutagenic activities comes from the ommochrome family. The present study suggests that squid skin ommochromes are pigments of therapeutic value in near future applications in the food or health sector.
\end{abstract}

Keywords: antimutagenic activity; antimicrobial activity, extraction optimization; FT-IR, ${ }^{1} \mathrm{H}$ NMR; squid skin ommochromes

\section{INTRODUCTION}

Due to the development of infectious diseases and degenerative processes associated with reactive oxygen species, the interest in finding natural compounds that can replace synthetic drugs, and which are safe and wholesome is fuelling one of the fastest expanding fields across several industries. In response to this trend, natural dyes and pigments from several food by-products are being used as food and cosmetic additives, among others things (Helkar $\boldsymbol{e}$ al., 2016). Among seafood by-products, jumbo squid skin is a valuable, underutilized source of pigments (Aubourg et al., 2016).

Marine organisms develop an extraordinary range of diverse compounds, including pigments with antioxidant, antimicrobial, and antimutagenic activities (Aquil et al., 2011). The pigments found in marine organisms, mostly distributed in the fatty tissues of marine fish and invertebrates, are usually synthesized within the tissues of photosynthetic bacteria, algae and higher plants, being the phycobilins, melanins, and carotenoids being the most studied pigments from seafood (Alasalvar and Taylor, 2002). Among the compounds responsible for the colour in the cephalopods are ommochromes, which are mainly synthesized in the skin of marine molluscs (Shamim et al., 2014). These chromatophores appear as small dots and contain red, yellow or brownish-black pigments. By controlling the size of the cells, they can vary their colour and even create changing patterns. Chromatophores are connected to the nervous system, and their size is determined by muscle contractions (Deravi et al., 2014). The metabolic precursor of these pigments is the amino acid tryptophan, from which compounds of varied shades are derived, such as ommatins (low molecular weight, thermolabile and of a faint colour) and ommins (high molecular weight, thermostable and which are related to intense colorations) (Sahmim et al., 2014). Ommochromes, like other pigments, produce colour in the biological system, preventing peroxidation in cellular liposomes caused by UV radiation (Dontsov et al., 1999; Sahmim et al., 2014) as well as functioning in the tryptophan detoxification process (Figon and Casas, 2019). The potential mechanism of action and reactivity of these molecules, established through theoretical studies, could exist by transferring electrons or transferring the hydrogen atom or both, depending on the chemical structure of the ommochrome (Romero and Martinez, 2015). In some cephalopod species, like Loligo vulgaris, Seppia officinalis, Octopus vulgaris and, Doryteuthis pealeii the main ommochrome identified is xanthommantin (Bolognese and Scherillo, 1974; Willimas et al., 2016).

Another species who synthesizes ommochromes is jumbo squid (Dosidicus gigas), and they have been mainly found in its skin. Normally, this anatomical region is discarded. The information on jumbo squid skin mostly comprises collagen and its products (Ezquerra-Brauer and Aubourg, 2019). Based on the available scientific literature, there is little information about the functional properties of skin ommochromes. Recently, it has been discovered that ommochromes from jumbo squid skin retarded the oxidation of fish oil (Aubourg et al., 2016) and prolonged the shelf life of two stored fish species in ice, linked to antioxidant and antimicrobial activities of these extracts (Ezquerra-Brauer et al., 2016, 2017). These pigments showed a yellow colour and absorbance peaks in the $300-450 \mathrm{~nm}$ region, and had an FT-IR spectrum that showed the presence of functional groups associated with the presence of ommochromes (Aubourg et al., 2016).

To explore a novel source of compounds with multiple potentials, the aim of this study was to document the antimicrobial and antimutagenic potential and chemical structure of pigmented compounds extracted from jumbo squid skin. This is the first study of ommochromes' antimicrobial activity against specific strains of bacteria and fungi, as well as their antimutagenic activity. The chemical characteristics of the extracted bioactive pigments was studied by analysing their physical and chemical characteristics. The results of this study provide a more information for the use of jumbo squid skin as another alternative source of bioactive pigments with biological activity. 


\section{MATERIAL AND METHODS}

\section{Materials}

Ten jumbo squids (D. gigas) were purchased from a local establishment in Hermosillo, Mexico $\left(29^{\circ} 05^{\prime} 56^{\prime \prime} \mathrm{n} 110^{\circ} 57^{\prime} 15^{\prime \prime} \mathrm{w}\right)$, and immediately skinned. The length and weight of the squid specimens ranged from 100 to $150 \mathrm{~cm}$ and from 40 to $60 \mathrm{~kg}$, respectively. The skin (about $50 \mathrm{~cm}$ length) was frozen at $-80{ }^{\circ} \mathrm{C}$, freeze-dried (Labconco, Kansas City, MO, USA) for 2 days and grinded Samples $(100 \mathrm{mg})$ were put in polyethylene bags, vacuum sealed and kept at -20 ${ }^{\circ} \mathrm{C}$ until analyses. All chemicals used were of analytical reagent grade and purchased from Sigma-Aldrich (St. Louis, MO, USA).

\section{Pigment Extraction}

Freeze-dried skin is a mixture of mainly protein and pigments; acidified methanol does not dissolve collagenous and stromal proteins and, at the same time, it is recommended as an ommochrome remover (Van den Branden and Decleir, 1976). Therefore, in this work pigment extraction was prepared with acidified methanol. The extraction method consisted of treatments of different temperatures temperature $\left(25,35\right.$, and $\left.45^{\circ} \mathrm{C}\right)$ and sonication times $(5,10$, and 15 min). Suitable conditions for obtaining pigmented extracts were established by factorial design in which the dependent variables were yield and antioxidant activity and the independent variables were temperature and sonication time.

Briefly, the pigment extraction process consisted of the homogenization of 20 volumes of freeze-dried skin (w/v) in acidified methanol (99:1 methanol: $\mathrm{HCl}$ ), followed by centrifugation (Model Biofuge Stratos, Thermo Scientific, Germany) at $10,000 \times g$ for $15 \mathrm{~min}$. The methanol was removed using a rotary evaporator (R-100, Büchi, Switzerland) and further evaporated using nitrogen gas. The dry extracts were stored in an inert nitrogen atmosphere, at $-80{ }^{\circ} \mathrm{C}$, prior to further analysis. The dried yield was calculated, and stock solutions were prepared to assess antioxidant activity.

Extraction yield was calculated gravimetrically, using the weight of the skin sample as a reference. Pigment yield was calculated as follows:

Pigment yield $(\%)=[($ dried pigmented extract $(\mathrm{g})) /($ dried squid skin $(\mathrm{g}))] \times 100$.

The antioxidant activity was established by the oxygen radical absorbance capacity (ORAC) method. The ORAC method was carried out according to previous methodology (Garret et al., 2010) but with modifications. The fluorescence loss of fluorescein was monitored during $90 \mathrm{~min}$ at $37^{\circ} \mathrm{c}$ in the presence of 2,2'-azobis(2-amidinopropane) dihydrochloride (AAPH). Each sample $(0.5 \mathrm{mg} / \mathrm{ml})$ was tested in triplicate and compared with a standard curve to express results as Trolox (6-hydroxy-2,5,7,8-tetramethylchroman-2-carboxylic acid) equivalents.

Extraction conditions for measuring the antimicrobial and antimutagenic activities were selected as the better conditions (temperature and sonication time) for yield and antioxidant activity.

\section{Antimicrobial Activity}

The antimicrobial effects of the extracts $(10 \mathrm{mg}$ of extract) were assessed following the disc diffusion test as reported previously (Fatrcová-Šramková $\boldsymbol{e} t$ al., 2016). Antimicrobial activity of the jumbo squid skin pigmented extracts (JSSE) were tested against three Gram-negative bacteria (Haemophilus influenza CCM 4456, Klebsiella pneumoniae CCM 2318, Salmonella enterica subs enterica CCM 3807), four Gram-positive bacteria (Bacillus cereus CCM 2010, Clostridium perfringens CCM 4991, Listeria monocytogenes CCM 4699, Staphylococcus aureus subs. aureus CCM 2461), six microscopic filamentous fungi (Aspergillus clavatus, A. flavus, A. versicolor, Penicillium chrisogenum, $P$. griseofulvum, $P$. expansusm) and three yeasts (Candida albicans CCM 8186, $C$. glabrata CCM 8270, C. tropicalis CCM 8223). Bacteria were collected from the czech collection of microorganisms and microscopic filamentous fungi were collected from the Department of Microbiology, Faculty of Biotechnology and Food Sciences, Slovak University of Agriculture in Nitra, Slovakia. The inhibition of microbial growth was measured around the impregnated discs. Antimicrobial activity is considered high, moderate, or trace/zero when the zone diameter is $>10 \mathrm{~mm}, 5-10 \mathrm{~mm}$ or $2-5 \mathrm{~mm}$, respectively, and negligible effect when the value is less than $2 \mathrm{~mm}$ (Boo et al., 2012).

\section{Antimutagenic Activity}

The Ames test was used to evaluate the antimutagenic activity of the squid skin extracts (Maron and Ames, 1983). The assay was performed using $100 \mu \mathrm{L}$ of
Salmonella typhimurium strains T98 and T100 grown overnight (1x109 cells $/ \mathrm{mL}), 100 \mu \mathrm{L}$ of pigment extracts $(0.005,0.05,0.5$, and $5.0 \mathrm{mg} / \mathrm{mL})$ and the mutagenic agent (Aflatoxin $\mathrm{B}_{1}, \mathrm{AFB}_{1}$ ) with activation system $(500 \mu \mathrm{L}$ S9 mix) in triplicate plates. Ten precent DMSO $(100 \mu \mathrm{l})$ without $\mathrm{AFB}_{1}$ was used as negative control. After incubation for $48 \mathrm{~h}$ at $37^{\circ} \mathrm{C}$, the number of revertant bacterial per plate were counted. The inhibition rate for mutagenic activity was calculated using the following equation:

Inhibition rate $(\%)=[((1-\mathrm{T})) / \mathrm{M}] \times 100$,

where $\mathrm{T}$ is the number of revertants per test sample plate in the presence of $\mathrm{AFB} 1$, and $\mathrm{M}$ is the number of revertants per plate in the positive control, after subtracting the number of spontaneous revertants from the numerator and denominator. The AFB1 mutagenesis inhibition is considered strong, moderate or weak when the values are high $\tan 60 \%, 40-60 \%$ or $20-40 \%$, respectively, and negligible when the value is lower than $20 \%$ (Ikke et al., 1999).

\section{Chemical Structure Analysis}

For the analysis the JSSE were freeze-dried and then evaluated.

The solubility test was performed using $5 \mathrm{~mL}$ of the following solvents: acetone, ethyl ether, chloroform, $77 \%$ aqueous sulfuric acid, and methanol-2\% $\mathrm{HCl}$. In each solvent, $5 \mathrm{mg}$ of freeze-dried extracts was dissolved and stirred for $5 \mathrm{~min}$ at $24^{\circ} \mathrm{C}$ (Van den Branden and Decleir, 1976).

The absorbance of the extracted pigments was measured using a Cary 50 spectrophotometer (Agilent Technologists, Ciudad de México, México) over the wavelength range of $200-600 \mathrm{~nm}$. The blank solution was methanol.

Fourier transform-infrared spectrum of extracted pigments was obtained from pellets, prepared with $1 \mathrm{mg}$ sample and $100 \mathrm{mg}$ of dry potassium bromide $(\mathrm{KBr})$ The spectra were recorded using and infrared spectrophotometer, Perkin Elmer FT-IR Spectrum GX (Waltham, MA, USA). The FT-IR spectrum (16 scans) was analysed in transmittance mode between 400 and $4000 \mathrm{~cm}^{-1}$.

Then, ${ }^{1} \mathrm{H}$ NMR analysis was measured at $25^{\circ} \mathrm{C}$ on a Bruker Avance 400 nuclear magnetic spectrometer (Billerica, MA, USA) operating at $400 \mathrm{MHz}$. For the experiments, approximately $1 \mathrm{mg}$ of freeze-dried pigments was dissolved in 0.5 $\mathrm{ml}$ of a $1 \%$ (v/v) deuterated potassium hydroxide $40 \%$ solution with deuterated water. Dimethylsilapentane-5-sulfonic acid (DSS) was used as a reference. The spectral window was $20 \mathrm{ppm}$.

\section{Statistical Analysis}

A $3 \mathrm{X} 3$ factorial randomized complete block design was used to obtain an optimal combination of temperature and sonication time that yielded a high level of pigmented extracts with the high antioxidant activity. The selection of the levels of temperature $\left(25,35\right.$ and $\left.45^{\circ} \mathrm{C}\right)$ and sonication time $(5,10$, and $15 \mathrm{~min})$ tested was based on preliminary studies. The experiment design and statistical analysis were carried out using JMP software (SAS, Cary, NC, USA). Differences between the means were compared using Tukey's test $(p<0.05)$.

Data of the jumbo squid extracted pigment's physicochemical characterization, antimicrobial and antimutagenic activities were based on the average of three determinations. For spectroscopic analysis, descriptive statistics were used to analyse the data (Glover and Mitchell, 2015). For solubility test and antimicrobial and antimutagenic activities, the variations among replicates was $<5 \%$. The mean values of the three trials and standard deviations were calculated.

\section{RESULTS AND DISCUSSION}

\section{Pigment Extraction}

The results of yield and antioxidant activity (Tab 1) indicated that a high yield and high antioxidant activity were obtained when applying a combination of $25^{\circ} \mathrm{C}$ and $5 \mathrm{~min}$ of sonication time. The optimal combination of temperature and sonication time was established by factorial analysis. When the effect of both factors was evaluated, it was observed that the levels of temperature and sonication time affected both positively and negatively the dependent variables ( $p$ $<0.05$ ). Additionally, an interaction between both factors $(p<0.05)$ was found The yield of all treatments ranged between 580 and $690 \mathrm{mg}$ of pigment extract per $100 \mathrm{~g}$ of fresh squid skin, whereas the antioxidant activity was between 80 and $178(\mu \mathrm{mol} \mathrm{TE} / \mathrm{g})$. The extraction yield of pigments increased because the sonication time was longer (Tab 1). However, the prolonged exposure of samples to ultrasonic sounds can render antioxidant compounds inactive (Tab 1). 
Table 1 Yield and antioxidant activity of pigmented extracts with different temperature-sonication treatments ${ }^{1}$ from jumbo squid skin.

\begin{tabular}{|c|c|c|c|c|c|c|}
\hline \multirow{3}{*}{$\begin{array}{l}\text { Temperature }{ }^{2} \\
\left({ }^{\circ} \mathrm{C}\right)\end{array}$} & \multicolumn{6}{|l|}{$\begin{array}{l}\begin{array}{l}\text { Sonication Time } \\
(\mathrm{min})\end{array} \\
\end{array}$} \\
\hline & \multicolumn{2}{|l|}{5} & \multicolumn{2}{|l|}{10} & \multicolumn{2}{|l|}{15} \\
\hline & $\begin{array}{l}\text { Yield } \\
\text { (mg/100 g skin) }\end{array}$ & $\begin{array}{l}\text { Antioxidant } \\
\text { Activity } \\
(\mu \mathrm{mol} \mathrm{TE} / \mathrm{g})\end{array}$ & $\begin{array}{l}\text { Yield } \\
\text { (mg/100 g skin) }\end{array}$ & $\begin{array}{l}\text { Antioxidant } \\
\text { Activity } \\
(\mu \mathrm{mol} \mathrm{TE} / \mathrm{g})\end{array}$ & $\begin{array}{l}\text { Yield } \\
\text { (mg/100 g skin) }\end{array}$ & $\begin{array}{l}\text { Antioxidan } \\
\text { Activity } \\
(\mu \mathrm{mol} \mathrm{TE} / \mathrm{g})\end{array}$ \\
\hline 25 & $650 \pm 5.5^{\mathrm{Bb}}$ & $178 \pm 2.1^{\mathrm{Aa}}$ & $650 \pm 5.5^{\mathrm{Bb}}$ & $168 \pm 3.5^{\mathrm{Ab}}$ & $638 \pm 6.2^{\mathrm{Ca}}$ & $128 \pm 2.8^{\mathrm{Ac}}$ \\
\hline 35 & $659 \pm 4.1^{\mathrm{Bb}}$ & $150 \pm 4.0^{\mathrm{Ba}}$ & $659 \pm 4.1^{\mathrm{Bb}}$ & $135 \pm 1.1^{\mathrm{Bb}}$ & $685 \pm 8.9^{\mathrm{Ba}}$ & $115 \pm 1.7^{\mathrm{Bc}}$ \\
\hline 45 & $679 \pm 6.1^{\mathrm{Ab}}$ & $130 \pm 5.0^{\mathrm{Ca}}$ & $679 \pm 6.1^{\mathrm{Ab}}$ & $90 \pm 7.5^{\mathrm{Cb}}$ & $690 \pm 4.1^{\mathrm{Aa}}$ & $80 \pm 5.0^{\mathrm{Cc}}$ \\
\hline
\end{tabular}

${ }^{1}$ Values are the mean of three repetitions \pm standard deviation.

${ }^{2}$ Capital letters in columns denote differences by effect of the temperature $(p<0.05)$.

${ }^{3}$ Small letters in rows denote differences by effect of sonication time $(p<0.05)$.

The two variables used in this study have been previously reported as relevant to the extraction and antioxidant activity of several biological compounds, including pigments (Maran et al., 2015; Belwal et al., 2016; Mokrani and Madani, 2016). It has been reported extensively that temperatures above $30^{\circ} \mathrm{C}$ help with the extraction of biologically active compounds (Maran $\boldsymbol{e t}$ al., 2015; Belwal $\boldsymbol{e}$ al., 2016; Mokrani and Madani, 2016). As can be observed in table 1, for JSSE pigmented extracts, temperature had a significant effect on the extraction yield; however, when temperature increased above $35{ }^{\circ} \mathrm{C}$, antioxidant activity decreased. This type of behaviour has been observed in other studies that dealt with the extraction of antioxidant compounds (Michiels et al., 2012). Maintaining $25{ }^{\circ} \mathrm{C}$ makes the extraction both cheaper and safer, avoiding the generation of vapours and the usage of heat plates or heat sources. Another advantage is assuring the preservation of the antioxidant activity of the pigmented extract.

The use of sonication in the extraction of compounds has been extensively reported. Sonication facilitated the lysis of the cells in which the pigments are occluded. Its effectiveness in squid skin relies on the formation of vacuum bubbles in the solvent because of low-pressure and high-pressure cycles mediated by the ultrasonic waves. When the bubbles implode, the saccules that contain pigments and other compounds soluble in methanol are released. The mechanical forces eject the compounds, which are later recuperated. Similar patterns to the results obtained in this work, were observed in other foodstuffs from different origins (Altermimi et al., 2015). The energy release from sonic waves is not completely efficient; some of it is liberated to the environment and eventually ends up generating free radicals via sonolysis in water and aqueous solutions (Castellanos et al., 2001). Evidence has been found of the ultrasound-mediated formation of free radicals in red wine, specifically hydroxyethyl radicals (Zhang et al., 2015). It is theorized that the antioxidants exert their function with these molecules, thus resulting in a decrease of functionality (Zhang et al., 2015).

The best combinations of temperature and sonication conditions yielded 635 $\mathrm{mg} / 100 \mathrm{~g} \mathrm{JSS}$ and $178 \mu \mathrm{mol} \mathrm{TE} / \mathrm{g}$ JSSE hydrogen atom transfer capacity (ORAC test). Previously it was detected that jumbo squid pigmented extracted with ethanol-acetic acid (Aubourg et al., 2016) measured using the ORAC assay showed a value of $15.4 \mu \mathrm{mol} \mathrm{TE} / \mathrm{g}$. Therefore, JSSE contains redox components which are ten times more active than those previously reported. Under these conditions, JSSE pigments were extracted to evaluated their potential antimicrobial and antimutagenic activities.

\section{Antimicrobial Activity}

The analysis results of antimicrobial activity of JSSE against selected microbes are shown in table 2. Haemophilus influenza, Salmonella enterica of Gramnegative bacteria, Listeria monocytogenes, Satphlococcus aureus, of Grampositve bacteria, Aspergillus clavatus, Penicillium expanssum, of fungi, and Candida albicans of yeast showed a clear zone formation of growth inhibition. Antimicrobial activity in Bacillus cereus, Klebsiela pneumoniae, from microscopic fungi Penicillium chrisogenum and, from candida Candida tropicalisscored was relative low compared to other strains. The JSSE in the case of $S$. enterica showed the high antimicrobial activity.

The antimicrobial activity detected in JSSE pigments could be due to the amphipathic nature of the ommochromes that gives them the ability to interact with cell membrane components, as well as other bacterial protection factors. At this time a widespread range of natural substances are recognized as having antimicrobial activity, but few studies related to antimicrobial efficacy of squid skin pigments have been done, and some are not made up. Some mechanisms of antibacterial activity, of similar compounds to those reported in the squid skin, are (i) the ability to form pores in cells and (ii) breaking cell walls (Senan, 2015) As to the antifungal activity, the main mechanisms recognized for this are attacks on the membrane, microtubules, RNA, and synthesis of ergosterol, among others. However, in the case of the compounds present in the sepia ink, the antifungal activity was related to an imbalance in the redox balance of the fungus (Fahmy et al., 2014).
Table 2 Antimicrobial effect of the squid skin extract on bacteria, yeasts, and fungi ${ }^{1}$

\begin{tabular}{lll}
\hline Microorganism & $\begin{array}{l}\text { Inhibition zone size } \\
(\mathrm{mm})^{2}\end{array}$ & $\begin{array}{l}\text { Inhibition } \\
(\%)\end{array}$ \\
\hline Bacteria & $\mathrm{T}$ & $39.4 \pm 0.3$ \\
Bacillus cereus & $\mathrm{T}$ & $45.5 \pm 0.8$ \\
Clostridium perfringens & $\mathrm{M}$ & $54.5 \pm 0.4$ \\
Haemophilus influenza & $\mathrm{T}$ & $39.4 \pm 0.4$ \\
Klebsiella pneumoniae & $\mathrm{M}$ & $60.7 \pm 0.1$ \\
Listeria monocytogenes & $\mathrm{M}$ & $57.8 \pm 1.3$ \\
Staphylococcus aureus subs. & $\mathrm{H}$ & $93.9 \pm 0.3$ \\
Aureus & $\mathrm{T}$ & \\
Salmonella enterica subs. Enterica & $\mathrm{T}$ & $42.4 \pm 2.1$ \\
\hline Fungi & $\mathrm{T}$ & $48.4 \pm 0.7$ \\
Aspergillus flavus & $\mathrm{M}$ & $39.4 \pm 3.2$ \\
Aspergillus versicolor & $\mathrm{T}$ & $42.4 \pm 2.4$ \\
Aspergillus clavatus & $\mathrm{T}$ & $48.5 \pm 1.1$ \\
Penicillium chrisogenum & $\mathrm{M}$ & \\
Penicillium griseofulvum & & $66.7 \pm 1.5$ \\
Penicillium expansum & $\mathrm{M}$ & $33.3 \pm 2.3$ \\
\hline Yeast & $\mathrm{T}$ & $42.4 \pm 0.2$ \\
Candida albicans & $\mathrm{M}$ & \\
Candida tropicalis & Candida glabrata &
\end{tabular}

${ }^{1}$ Data: mean \pm standard deviation of three repetitions.

${ }^{2}$ Legend: $\mathrm{H}->$ than $10 \mathrm{~mm}, \mathrm{M}->5-10 \mathrm{~mm}, \mathrm{~T}->2-5 \mathrm{~mm}$.

\section{Antimutagenic Activity}

Antimutagenic activity of squid skin pigments has not been previously reported Although, the pigments decreased the revertants/plate in a dose-response relationship in both S. typhimurium TA98 and TA100 strains (Fig 1), only in TA98 was the percentage of inhibition considered effective, from strong (49-87 $\%)$ to moderate (38\%), and a very low inhibition percentage was observed in $S$. typhimurium TA $100(<14 \%)$.

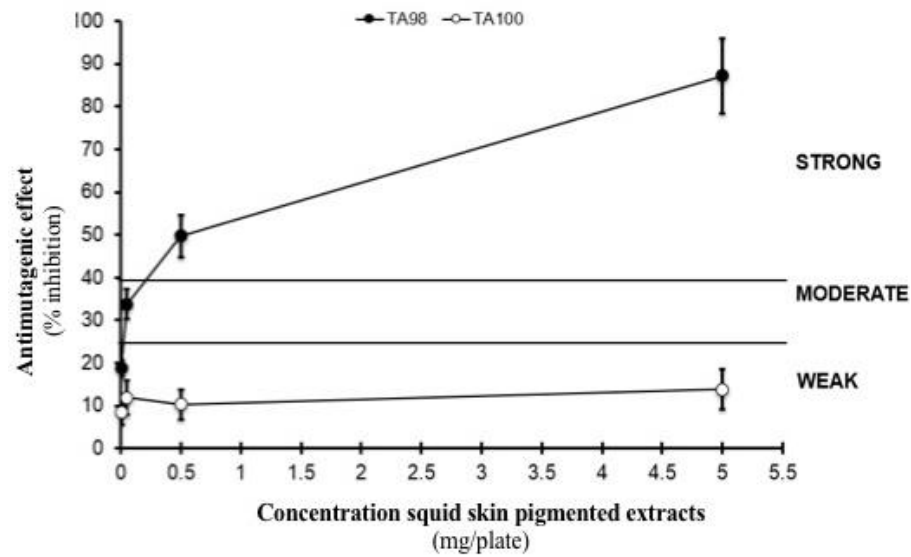

Figure 1 Effect of jumbo squid skin pigments on the mutagenicity induced by aflatoxin $B_{1}$, based on Salmonella typhymurium TA 98 and TA 100 . All values represent mean value of triplicate determination \pm standard deviation.

The very low inhibition percentage observed in S. typhimurium could be due to the complexity of the sample. Therefore, these results suggested that the extracted pigments only protect the genetic material against only one type of mutation, a frameshift mutation detected by TA98 strain, and not a base pair 
substitution, because the pigments were not capable of producing at least a moderate inhibition of mutation induced by $\mathrm{AFB}_{1}$ in TA100 strains (Jurado et al., 1993).

It is known that mutations induced by numerous mutagens were reduced by active oxygen scavengers (Osuna et al., 2016). Furthermore, it was reported that some antioxidant compounds could prevent mutations because they can induce the synthesis of antioxidant enzymes (Alasalvar and Taylor, 2002). In the case of ommochromes, which are the main class of pigments in cephalopods, they have been reported to act as electron accepting or donating systems, as well as tryptophan detoxification products (Shamim et al., 2014).

\section{Chemical Structure Analysis}

The reddish colour of JSSE suggests that certain types of ommochromes compounds exist in the obtained extract (Van den Branden and Decleir, 1976) To corroborate the nature of the components in the JSSE, solubility tests were performed (Tab 3), and the behaviour detected was similar to that expected for ommochrome (Van den Branden and Decleir, 1976). Therefore, the JSSE solubility behavior of the compounds present in the obtained extract can be associated with the presence of ommochromes

Table 3 Solubility tests of the squid skin extract ${ }^{1}$

\begin{tabular}{lcc}
\hline Solvent & $\begin{array}{c}\text { Squid Skin } \\
\text { Extract }^{2}\end{array}$ & $\begin{array}{c}\text { Ommochromes } \\
\text { Reported Behavior }^{3}\end{array}$ \\
\hline Distilled water & NS & NS \\
Hydrochloric acid 5 M & CS & CS \\
Acetone & NS & NS \\
Potassium hydroxide 20\% & CS & CS \\
Acetic acid & PS & PS \\
Methanol & NS & NS \\
Acidified methanol & CS & CS \\
Sulfuric acid 0.25 M & CS & CS \\
Chloroform & NS & NS \\
\hline
\end{tabular}

${ }^{1}$ Data: all analyses were run in triplicate.

${ }^{2}$ Legend: NS - no solubility, PS - poor solubility, CS - complete solubility.

${ }^{3}$ Reference: Van den Branden and Decleir (1976).

To confirm whether the pigments extracted from jumbo squid skin contained ommochromes UV-Vis, FT-IR, and ${ }^{1} \mathrm{H}$ NMR spectroscopies were employed. The UV-Vis spectroscopy of extracted pigments had an absorption maximum of 440 $\mathrm{nm}$ (Fig 2), which is similar to those red-pigments compounds previously reported in squid D. pealeii (Williams et al., 2016). Ommochromes are usually distinguished by their specific absorbance spectra; this characteristic implied that the squid pigments contain ommins, one of the two groups of ommochromes (Shamim et al., 2014). Moreover, the ${ }^{1} \mathrm{H}$ NMR spectrum (Fig 3) was similar to those of ommins (Kumar et al., 2018). The ${ }^{1} \mathrm{H}$ NMR spectrum indicated aromatic protons at $\delta 7.4 \mathrm{ppm}$ (singlet) and at $7.2 \mathrm{ppm}$ (singlet) and, functional group adjacent to a methyl carbon at $\delta 3.8$ (triplet) and at $3.0 \mathrm{ppm}$ (multiplet).

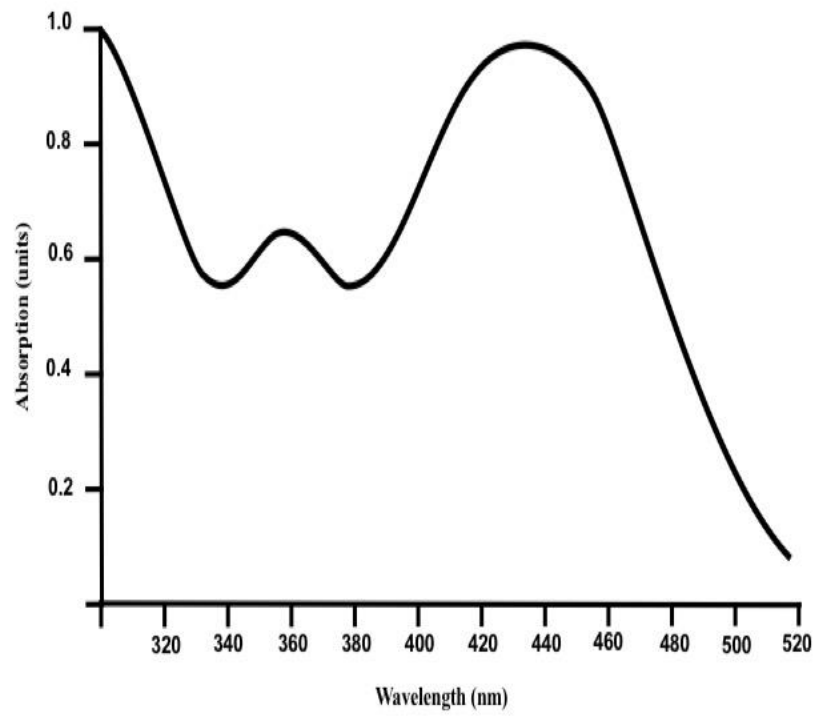

Figure 2 UV-Vis spectrophotometric spectra of jumbo squid skin pigments.

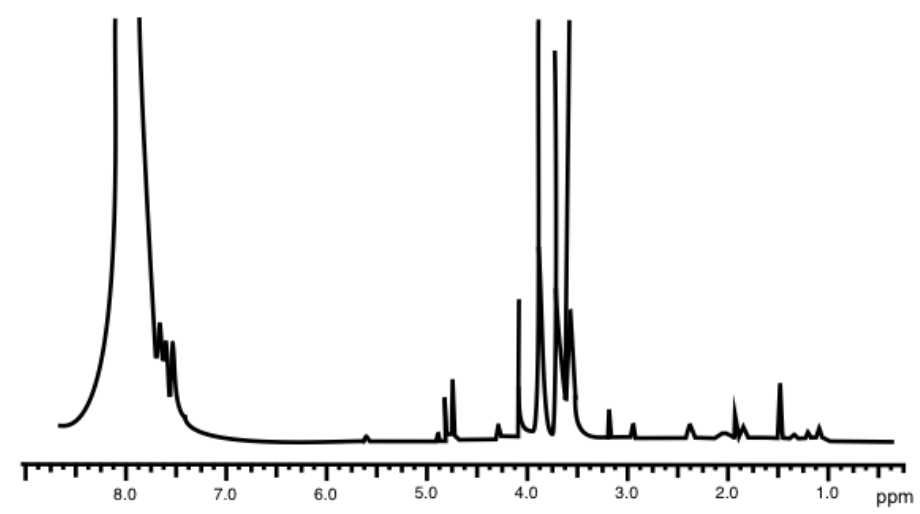

Figure $3{ }^{1} \mathrm{H}$ NMR spectrophotometric spectra of jumbo squid skin pigments.

Infrared spectroscopy provides more information regarding the chemica composition and conformation of the obtained pigments. The FT-IR spectra (4000-400 $\mathrm{cm}^{-1}$ ) of the pigments (Fig 4) represented those reported for ommochromes (Bolognese and Scherillo, 1974). The main signals observed were at $3550-3100 \mathrm{~cm}^{-1}(\mathrm{~N}-\mathrm{H}), 3000-2700 \mathrm{~cm}^{-1}(\mathrm{C}-\mathrm{H}$ stretching vibrations $)$, $1500-1425 \mathrm{~cm}^{-1}(\mathrm{~N}-\mathrm{H}$ and $\mathrm{C}-\mathrm{H}$ bending vibrations $), 1240-1050 \mathrm{~cm}^{-1}(\mathrm{C}-\mathrm{O}$ and $\mathrm{C}-\mathrm{N}$ stretching vibrations) (Dyer, 1965). Furthermore, wave numbers for carbomethoxy $\mathrm{C}=\mathrm{O}(1740 \mathrm{~cm}-1)$ and quinonic $\mathrm{C}=\mathrm{O}\left(1670 \mathrm{~cm}^{-1}\right)$ indicated that squid pigments contained ommochromes compounds of the xanthommatin-type (Bolognese and Scherillo, 1974).

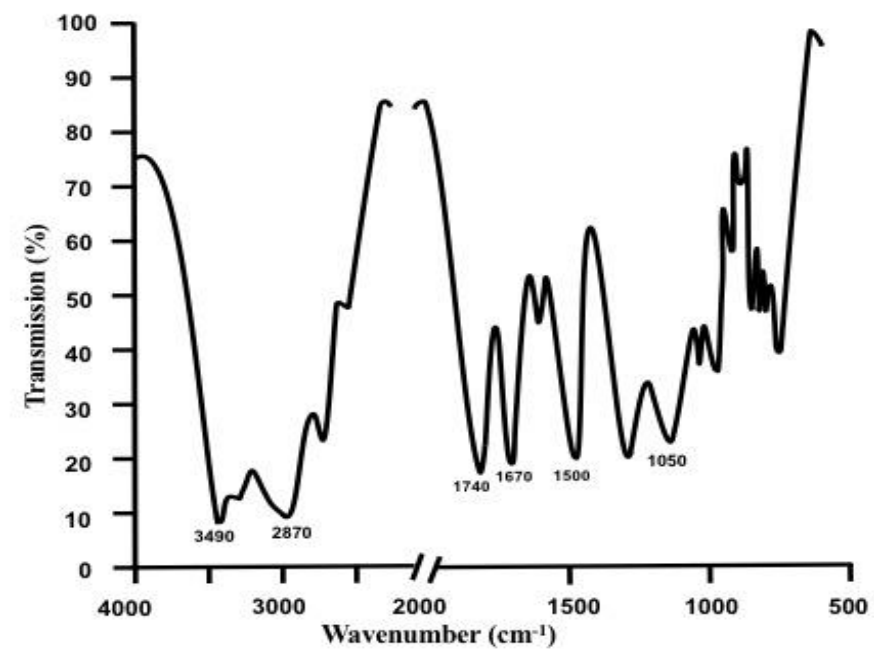

Figure 4 FTIR spectrophotometric spectra of jumbo squid skin pigments.

\section{CONCLUSION}

Jumbo squid skin pigments contain antibacterial and antimutagenic compounds, which were detected in the methanol- $\mathrm{HCl}$ soluble extracts. The extraction of bioactive pigments from jumbo squid skins was determined by both temperature and sonication time. Additionally, the present study suggests that one of the main compounds that exerted the biological activity in squid skin pigmented extracts were ommatins, specifically of the xanthommatin type. However, future studies need to focus on the identification of the specific antimicrobial and antimutagenic mechanisms of the compounds present in the jumbo squid skin pigmented extract.

Acknowledgments: This research was supported by CONACyT under grant 107102 and 2174. Chan-Higuera was supported by a doctoral fellowship from CONACyT.

Conflicts of Interest: All authors declare that there are no conflicts of interest regarding the publication of this paper.

\section{REFERENCES}

ALASALVAR, C., TAYLOR, T. 2002. Seafoods: Quality, technology and nutraceutical applications. Berlin: SPRINGER-VERLAG, 224 p. ISBN 978-3540-42476-5. http://dx.doi.org/10.1007/978-3-662-09836-3

ALTERMIMI, A., CHOUDHARY, R., WATSON, D.G., LIGHTFOOT, D.A 2015. Effects of ultrasonic treatments on the polyphenol and antioxidant content of spinach extracts. Ultrasonics Sonochemistry, 24, 247-255. https://doi.org/10.1016/j.ultsonch.2014.10.023 
AQUIL, F., ZAHIN, M., EL SAYED, K.A, AHMAD, I., ORABI, K., ARIF, J.M. 2011. Antimicrobial, antioxidant, and antimutagenic activities of selected marine natural products and tobacco cembranoids. Drug and Chemical Toxicology, 34(2), 167-179. https://dx.doi.org/ 10.3109/01480545.2010.494669

AUBOURG, S.P., TORRES-ARREOLA, W. TRIGO, M., EZQUERRABRAUER, J.M. 2016. Partial characterization of jumbo squid skin pigment extract and its antioxidant potential in a marine oil system. European Journal of Lipid Science and Technology, 118(9), 1293-1304. https://dx. doi.org/10.1002/ejlt.201500356

BELWAL, T., DHYANI, P., BHATT, I.D., RAWAL, R.S., PANDE, V. 2016 Optimization extraction conditions for improving phenolic content and antioxidant activity in Berberis asiatica fruits using response surface methodology (RSM). Food Chemistry, 207 ,115-124. https://dx.doi.org/10.1016/j.foodchem.2016.03.081

BOLOGNESE, A., SCHERILLO, G. 1974, Occurrence and characterization of a labile xanthommatin precursor in some invertebrates. Experientia, 30(3), 225226. https://dx.doi.org/article/10.1007/BF01934793

BOO, H.O., HWANG, S.H., BAE, CH.S., PARK, S.H., HEO, B.G. GORINSTEI, S. 2012. extraction and characterization of some natural pigments. Industrial Crops and Products, 40, 129-135. https://dx.doi.org./10.1016/j.indcrop.2012.02.042

CASTELlaNOS, M.M., REYMAN, D., SIEIRO, C., CALLE, P. 2001. ESRspin trapping study on the sonochemistry of liquids in the presence of oxygen Evidence for the superoxide radical anion formation. Ultrasonic Sonochemistry, 8(1), 17-22. https://dx.doi.org/10.1016/S1350-4177(99)00047-4

DERAVI, L.F., MAGYAR, A.P., SHEEHY, SP, BELL GR, MÄTHGER LM, SENFT SL, WARDILL TJ, LANE WS, KUZIRIAN AM, HANLON RT, HU EL, PARKER KK. 2014. The structure-function relationships of a natural nanoscale photonic device in cuttlefish chromatophores. Journal of the royal society intefase, 11(93), 20130942. https://dx.doi.org/full/1'.1098/rsif.2013.0942 DONTSOV, A.E., FEDOROVICH, I.B., LINDSTRÖM, M., OSTROVSKY, M.A. 1999. Comparative study of spectral andantioxidant properties of pigments from the eyes of two Mysis relicta (Crustacea, mysidacea) populations, with different light damage resistance. Journal of Comparative Physioliogy B, 169(3) 157-164. https://dx.doi.org/10.1007/s003600050206

DYER, J.R. 1965. Application of absorption spectroscopy of organic compounds. Englewood Clifs: PRENTICE-HALL, 22-57 p. ISBN 978-0130388100. http://dx.doi.org/10.1021/ed042p690.3

EZQUERRA-BRAUER, J.M., AUBOURG, S.P. 2019. Recent trends for the employment of jumbo squid (Dosidicus gigas) by-products as a source of bioactive compounds with nutritional, functional and preservative applications. International journal of food science and technology, 54(4), 987-998. https://dx.doi.org/10.111.ijfs. 14067

EZQUERRA-BRAUER, J.M., MIRANDA, J.M.; CEPEDA, A., BARROSVELAZQUEZ, J., AUBOURG, S.P. 2016. Effect of jumbo squid (Dosidicus gigas) skin extract on the microbial activity in chilled mackerel (Scomber scombrus). LWT-Food science and technology, 72, 134-140. https://dx.doi.org/10.106/j.1wt.2016.04.024

EZQUERRA-BRAUER, J.M., MIRANDA, J.M., CHAN-HIGUERA, J.E. BARROS-VELÁZZUEZ, J., AUBOURG, S.P. new icing media for quality enhancement of chilled hake (Merluccius merluccius) using a jumbo squid (Dosidicus gigas) skin extract. Journal of the sciencie of food and agriculture, 97(10), 30412-3419. https://dx.doi.org/10.1002/jsfa.8192

FATRCOVÁ-ŠRAMKOVÁ, K., NÔŽKOVÁ, J., MÁRIÁSSYOVÁ, M. KAČANIOVÁ, M. 2016. Biologically active antimicrobial and antioxidan substances in the Helianthus annuus 1. Bee pollen. Journal of Environmentla Science and Helath, Part B, 51(3), 176-181. https://dx.doi.org/abs/10.1080/03601234.2015.1108811

FAHMY, S.R., SOLIMAN, A., ALI, E.M. 2014. Antifungal and antihepatotoxic effects of sepia ink extract against oxidative stress as a risk factor of invasive poulmonary aspergillosis in neutropenic mice. African journal of traditional, complementary and alternative medicines, 11(3), 148-159. https://dx.doi.org/10.4314/ajtcam.v11i3.22

FIGON, F., CASAS, J. 2019. Ommochromes in invertebrates: Biochemistry and cell biology. Biological Reviews, 94(1), 156-183. https://dx.doi.org/epdf/10.111/brv.12.441

GARRETT, A.R., MURRAY, B.K., ROBISON, R.A., O'NEILL, K.L. 2010 Measuring antioxidant capacity using the ORAC and TOSC assays. Advanced Protocols In Oxidative Stress II, Methods In Molecular Biology (Methods and Protocols). Totowa: HUMANA PRESS. ISBN 978-1-60761-410-4. http://dx.doi.org//10.1007/978-1-60761-411-1

GLOVER, T.K., MITCHELL, K. 2015. An introduction to biostatistics. Long Grove: WAVELAND PRESS, 553 p. ISBN 978-1-4786-2779-4. http://dx.doi.org.:10.1001/jamainternmed.2014.4098.

HELKAR, P.B., SAHOO, A.K., PATIL, N.J. 2016. Review: Food industry byproducts used as functional ingredients. International journal of waste resources, 6(3), 1-6. https//dx.doi.org/10.4172/2252-5211.1000248

IKKEN, Y., MORALES, P., MARTÍNEZ, A., MARÍN, M.L., HAZA, A.I., CAMBERO, M.I. 1999. Antimutagenic effect of fruit and vegetable ethanolic extracts against n-nitrosamines evaluated by the Ames test. Journal of agricultural and food chemistry, 47(8),

https://dx.doi.org/abs/10.1021/jf990166n

JURADO, J., ALEJANDRE-DURÁN, E., PUEYO, C.1993. Genetic differences between the standard Ames tester strains TA100 and TA98. Mutagenesis. 8(6), 527-532. https://dx.doi.org/10.1093/mutage/8.6.527

KUMAR, A., WILLIAMS, T., MARTIN, C., FIGUEROA-NAVEDO, A., DERAVI, L. 2018. Xanthommatin-based electrochromic displays inspired by nature. ACS applied materials \& interfaces, 10(49), 43177-43183. https://dx.doi.org/ 10.1021/acsami.8b14123

MARAN, J. P., PRIYA, B., NIVETHA, C.V. 2015. Optimization of ultrasoundassisted extraction of natural pigments from Bougainvillea glabra flowers. $\begin{array}{llll}\text { Industrial crops and products. 63, 182-189. } & \end{array}$ https://dx.doi.org/10.1016/j.indcrop.2014.09.059

MARON, D., AMES, B. 1983. Revised methods for the Salmonella mutagenicity test. Mutattion research/enviornmental mutagenesis and related subjects, 113(3-4), 173-215. https://dx.doi.org/10.1016/0165-1161(83)90010-9

MICHIELS, J.A., KEVERS, C., PINCEMAIL, J., DEFRAIGNE, J.O., DOMMES, J. 2012. Extraction conditions can greatly influence antioxidan capacity assays in plant food matrices. Food chemistry, 130(4), 986-993. https://dx.doi.org/10.1016/j.foodchem.2011.07.117

MOKRANI, A., MADANI, K. 2016. Effect of solvent, time and temperature on the extraction of phenolic compounds and antioxidant capacity of peach (Prunus persica 1.) Fruit. Separation and purification technology, 162, 68-76. https://dx.doi.org/10.1016/j.seppur.2016.01.043

OSUNA-RUIZ, I., LOPEZ SAIZ, C.M., BURGOS-HERNÁNDEZ, A., VELAZQUEZ, C., NIEVES-SOTO, M., HURTADO-OLIVA, M.A. 2016. Antioxidant, antimutagenic and antiproliferative activities in selected seaweed species from Sinaloa, Mexico. Pharmaceutical Biology. 54(10), 2196-2210. https://dx.doi.org/full/10.3109/13880209.2016.1150305

ROMERO, Y., MARTINEZ, A. 2105. Antiradical capacity of ommochromes. Journal of molecular modeling, 21, 220. https://dx.doi/10.1007/s00894-0152773-3

SHAMIM, G., RANJAN, S.K., PANDEY, D.M., RAMANI, R. 2014 Biochemistry and biosynthesis of insect pigments. European journal of entomology, 111(2), 149-164. https://dx.doi.org/ doi: 10.14411/eje.2014.021

SENAN, V.P. 2015. Antibacterial activity of methanolic extract of the ink of cuttlefish, Sepia pharaonis against pathogenic bacterial strains. International journal of pharmaceutical sciences and research, 6(4), 1705-1710. https://dx.doi.org/10.3923/jm.2012.263.272

VAN DEN BRANDEN C., DECLEIR, W. 1976. A study of the chromatophore pigments on the skin of the cephalopod Sepia officinalis L. Biologisch jaarboek dodonaea, 44(7), 345-352. www.vliz.be/imisdocs/publications/247931.pdf

WILLIMAS, T.L., DIBONA, C.W., DINNEEN, S.R., JONES LABADIE, S.F., CHU, F., DERAVI, L.F. 2016. Contributions of phenoxazone-based pigments to the structure and function of nanostructured granules in squid chromatophores. Langmuir, 3(15), 3754-3759. https://dx.doi/10.1021/acs.langmuir.6b00243 ZHANG, Q.A., SHEN, Y., FAN, X. H., MARTIN, J.F.G., WANG, X., SONG Y. 2013. Free radical generation induced by ultrasound in red wine and mode wine: an EPR spin-trapping study. Journal of chemistry, 2013, 5950512. https://dx.doi.org/10.1155/2013/590512 